\title{
Dismissed with Prejudice: Gender Inequality in the Utah Legal Market
}

Collin Read Flake

Brigham Young University - Provo

Follow this and additional works at: https://scholarsarchive.byu.edu/etd

Part of the Sociology Commons

\section{BYU ScholarsArchive Citation}

Flake, Collin Read, "Dismissed with Prejudice: Gender Inequality in the Utah Legal Market" (2011). Theses and Dissertations. 3041.

https://scholarsarchive.byu.edu/etd/3041

This Thesis is brought to you for free and open access by BYU ScholarsArchive. It has been accepted for inclusion in Theses and Dissertations by an authorized administrator of BYU ScholarsArchive. For more information, please contact scholarsarchive@byu.edu, ellen_amatangelo@byu.edu. 
Dismissed with Prejudice: Gender Inequality in

the Utah Legal Market

Collin R. Flake

A thesis submitted to the faculty of

Brigham Young University

in partial fulfillment of the requirements for the degree of

Master of Science

Renata T. Forste, Chair

John P. Hoffmann

Benjamin G. Gibbs

Department of Sociology

Brigham Young University

August 2011

Copyright $@ 2011$ Collin R. Flake

All Rights Reserved 


\author{
ABSTRACT \\ Dismissed with Prejudice: Gender Inequality in \\ the Utah Legal Market \\ Collin R. Flake \\ Department of Sociology, BYU \\ Master of Science
}

With the increasing feminization of the legal profession in the United States over the last half century, past research has documented the prevalence and transformation of gender inequality in law firms. However, relatively little is known about gender inequality in small, conservative legal markets like Utah. This thesis examines data from the 2008-2009 Utah Attorney Advancement and Retention Survey. The analyses indicate that relative to their male colleagues, women earned less in 2007 and are less likely to procure higher quality job assignments than their peers. The most promising explanations for these disparities include employment sector, gender and motherhood statuses, and year of bar admittance. Contrary to the results of past work, analyses find little or no effect for several traditional predictors of gender gaps including marital status, mentoring, tokenism, firm size, and hours billed. Openended responses reveal that while overt discrimination exists to some degree in Utah firms, most inequitable treatment has taken on subtle forms such as exclusion from the "good old boys" network, perpetuation of traditional gender roles and stereotypes, and differential opportunity paths and structures.

Keywords: women lawyers, legal profession, inequality, discrimination, gender gap 


\section{ACKNOWLEDGMENTS}

I would first like to express my appreciation to the members of my graduate committee for making the completion of this thesis possible. I am grateful to Dr. Ben Gibbs for discussing theory and methodology with me throughout the writing process, and for assuring me that it was indeed possible to finish a project of this magnitude. I am also grateful to Dr. John Hoffmann for teaching me how to effectively analyze, interpret, and present data over the last four years, and for his constructive comments that substantially improved this thesis. I owe special thanks to my committee chair, Dr. Renata Forste, who has been a mentor in every sense of the word. I have no doubt that I could not have completed this research without her expertise and patient guidance.

Additionally, I would like to thank Dr. Marie Cornwall for offering critiques of earlier drafts and helping me better understand theories on gender, and Dr. Vaughn Call for collecting the data and allowing me to use it. I am also grateful to Dallan Flake, Emily Parker, Aaron Christensen, and Erin Moore for taking time out of their busy lives to provide helpful comments

on previous drafts. Finally, I thank my parents and my wife for showing genuine interest and providing support and encouragement throughout this project. 


\section{TABLE OF CONTENTS}

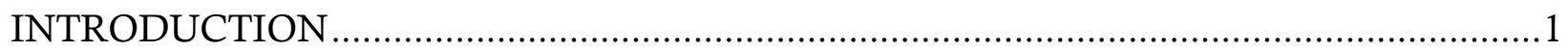

LITERATURE REVIEW ...................................................................................... 3

Theoretical Background and Existing Research..................................................... 3

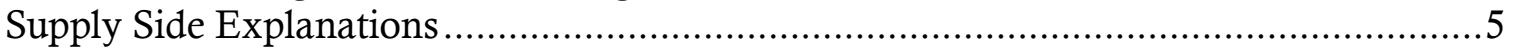

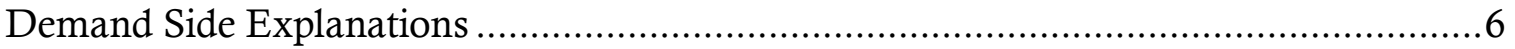

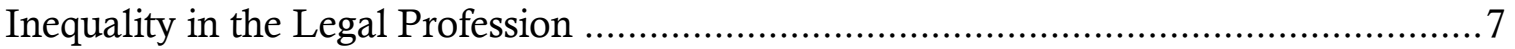

Employment Outcomes Associated with Gender Inequality in the Law ..................... 10

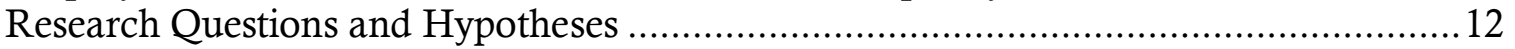

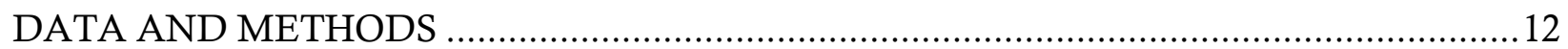

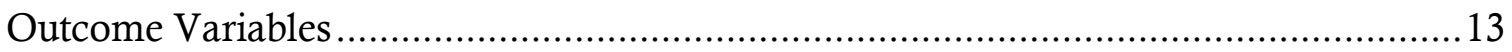

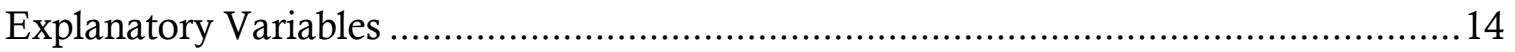

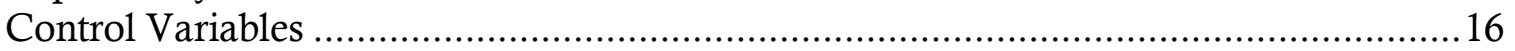

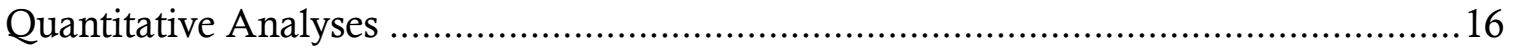

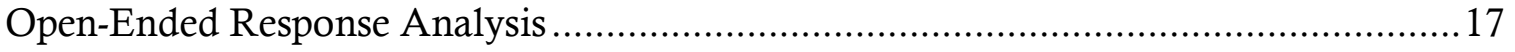

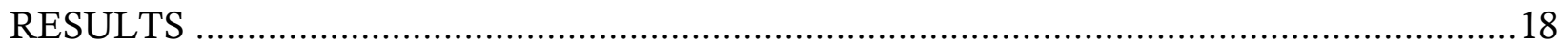

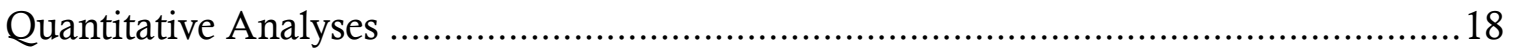

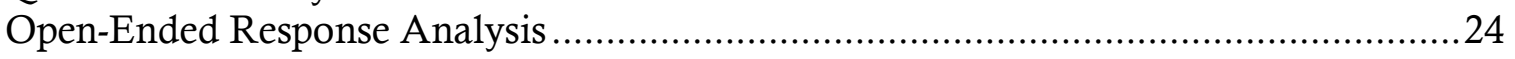

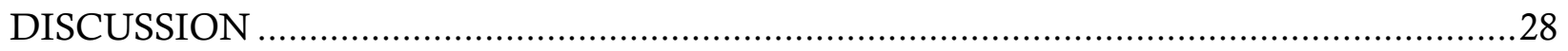

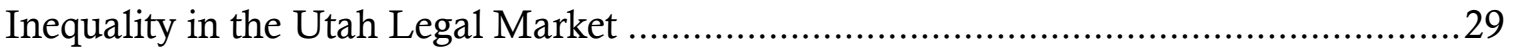

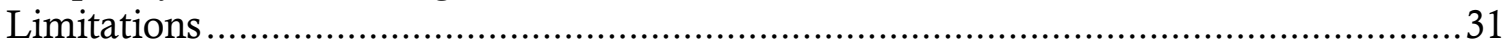

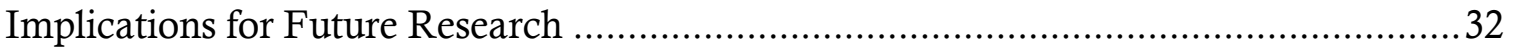

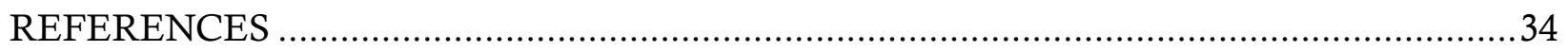

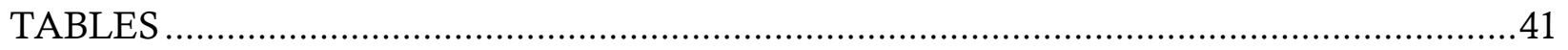




\section{TABLES}

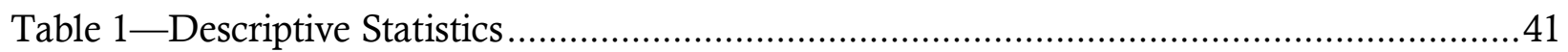

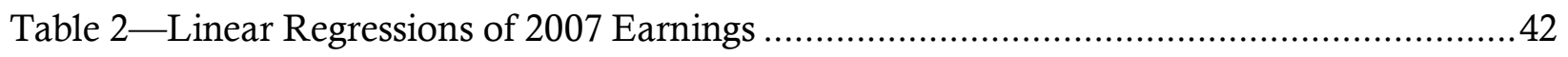

Table 3 - Logistic Regressions (Odds Ratios) of High Assignment Quality ...............................43 
An extensive body of economic and sociological research is devoted to the study of occupational gender inequality. While outcomes linked to gender inequality like the pay gap are ostensive, there is some uncertainty as to their less visible causes. Existing work suggests gender indirectly affects workplace equitability through various individual and structural mechanisms (England 2005; Huber 2007; Jacobs 1989; Reskin and Roos 1990; Ridgeway and Correll 2004a). While some theories posit that causes of differential employment outcomes include discrimination and the position of women in the labor market, others maintain that socialization, human capital investment, and career choice are the culprits. Whatever the case, research indicates the convergence of the gender pay gap has stalled (Bobbit-Zeher 2007; England 2005). The aim of this project is to explore the magnitude of gender inequality in a male dominated profession in one of the most conservative states in the country. From this unique perspective, the scope of gender inequality can be understood as a critical case where gender inequality and its correlates may be most readily discovered.

The increasing presence of women in the law over the last half century has produced a growing sociolegal literature evaluating their advancement and retention. Indeed, female attorneys have made considerable progress: they are no longer locked into low status jobs, they work in every legal sector, and they are increasingly promoted to partner (Epstein 2001). Notwithstanding the significant inroads women have made, persistent barriers continue to impede their advancement in the profession. Women are often sequestered from the "good old boys" network in the firm and consequently occupy lower status positions than men (Coffey and McLaughlin 2009; Pierce 1995). Women are also more likely than men to encounter sexual harassment, disparagement, and double standards (Kay and Gorman 2008; Laband and Lentz 1998; Rhode 2002) and have insufficient access to mentoring (Wallace 2001). Additionally, women with children are less likely to be promoted to partner, and mothers who achieve 
partnership earn less than other partners (Gorman and Kmec 2009; Noonan and Corcoran 2004). As a result of these barriers, women are often assigned to less prestigious casework (Epstein 1992; Kay and Hagan 2003; Pierce 1995; Rosenberg, Perlstadt, and Phillips 1993) and earn less money than their male colleagues (Chiu and Leicht 1999; Dinovitzer, Reichman, and Sterling 2009; Hersch 2003; Noonan, Corcoran, and Courant 2005).

To date, sociolegal research has disproportionately focused on legal markets in Canada, Chicago, and Los Angeles. Few, if any studies have considered the experience of women in a legal market as unique as Utah. Past work has noted the apparent decline of gender inequality with the increasing feminization of the legal profession (Epstein 2001). However, the rate of feminization in Utah practices-in terms of the number of women in the legal population-is considerably slower than the national rate. Approximately 38 percent of law school graduates in Utah are women compared to almost 50 percent nationally; 23 percent of Utah attorneys are women compared to 31 percent nationally; and 11 percent of partners in Utah are women compared to 19 percent nationally (American Bar Association 2010; Women Lawyers of Utah 2010). Utah is also one of the most politically conservative states in terms of residents who identify as conservative rather than moderate or liberal (Jones 2010). Moreover, the majority of Utah residents are members of the Church of Jesus Christ of Latter-day Saints (LDS), a religion which promotes traditional gender roles and family formation. ${ }^{1}$ The slow feminization of Utah's legal profession, coupled with its conservative political and religious climate, makes it an intriguing and atypical setting for the study of gender inequality.

This thesis provides an integrated view of gender inequality in the Utah legal market by (1) analyzing numerous factors empirically linked to inequality and (2) examining lawyers'

\footnotetext{
${ }^{1}$ LDS doctrine on the family is outlined in The Family: A Proclamation to the World, which states that "fathers are to preside over their families. . . . and are responsible to provide the necessities of life and protection for their families. Mothers are primarily responsible for the nurture of their children." We would expect these paternalistic beliefs and practices to negatively affect the advancement of women in predominantly male professions like the law.
} 
experiences with perceived discrimination. Utilizing survey data of attorneys who were admitted to the Utah bar between 1985 and 2005, I analyze differential employment outcomes. Specifically, I focus on earnings and job assignment quality. I expect the analyses to yield evidence of a gender gap in earnings and assignment quality and I intend to determine which individual and structural factors are most responsible for the inequality. Drawing upon previous work that uses a supply and demand framework to explain the influence of gender on women's attainment within organizations (England 2005; Hull and Nelson 2000; Kay and Hagan 1998; Reskin 1993; Ridgeway and Correll 2004a), this thesis begins with a discussion of the origins, mechanisms, and outcomes associated with gender inequality in the legal profession.

\section{LITERATURE REVIEW}

\section{Theoretical Background and Existing Research}

No singular theory encompasses the complex origin and various processes of occupational gender inequality. Although it is beyond the scope of this thesis to explore each theoretical tributary, it is necessary to consider perspectives that shape views of gender in the legal profession. One such perspective posits that gender stratification originated with the biological differences between men and women, like reproductive and lactation patterns. Until the latter half of the 20th century, the arduous and time-consuming nature of childbirth and nursing limited the participation of childbearing women in the labor force (Huber 2007). Despite shorter breastfeeding sessions and the invention of infant formulas that afford women more time, perceptions about women's roles and abilities remain deeply rooted in their biology (Huber 2007). In the legal profession, assumptions about the biology of women center on emotional characteristics and diminished commitment to work due to familial responsibilities (Epstein 2001; Kanter 1978; Rhode 1988). 
Other conceptualizations of the gender system attribute inequality to status beliefs about gender and motherhood. Gender status beliefs in the workplace influence behaviors and evaluations, resulting in several impediments to the advancement of women (Ridgeway and Smith-Lovin 1999). "Gender becomes an important component of interactional processes because the problems of organizing interaction evoke cultural schemas that reinforce continual sex categorization" (Ridgeway 1997:219). Ridgeway and Correll (2004b) argue that discrimination in some workplaces is more strongly associated with the motherhood role than with gender alone. They further assert that motherhood status negatively affects evaluations of a woman's competence and suitability for promotion. In fact, employed mothers suffer a five percent wage penalty per child net of other factors that determine compensation (Budig and England 2001). Gender and motherhood status beliefs are pervasive in the law, where the upper echelons are dominated by men and mothers who attain partnership earn less than other partners (Noonan and Corcoran 2004).

Another perspective argues that sex segregation in the workplace is a persistent component of the gender system. Traditionally, society reinforces the view that intelligence and authority are predominantly masculine qualities (Padavic and Reskin 2002). Roos and Reskin argue that these "deep-seated stereotypes about differences between the sexes and assumptions about their proper roles provide an often invisible foundation for many [organizational practices] and encourage sex 'traditional' decisions by individuals in the labor market" (1984:237). Women are encouraged to enter typically feminine jobs like care work, which pays both male and female workers less than other occupations (England, Budig, and Folbre 2002). Although employment sectors have become more sex-integrated in recent years, the pace of integration has stalled and most women remain in traditional female employment roles (Boraas and Rodgers 2003; Padavic and Reskin 2002). The range of inequity that follows from sex 
segregation includes the deprecation of women's work, limited mobility on the authority hierarchy, and the pay gap (England 2005; Jacobs 1989; Reskin 1993). Stereotypes that promote sex segregation are deeply embedded in the structure of the legal labor market where men are viewed as "Rambo litigators" and women are seen as "mothering paralegals" (Pierce 1995).

A comprehensive understanding of gender inequality requires the examination of mechanisms linking gender to unequal outcomes (Reskin 2003). Past work has identified a number of supply and demand side mechanisms contributing to labor market gender inequality. Supply side explanations emphasize individual factors such as socialization, personal choice, and human capital investment. Discrimination, position within the labor market, and devaluation of female occupations constitute demand side explanations. While economists apply the supply dynamic and sociologists favor the demand perspective (England 2005), the most accurate assessment of gender inequality is viewed through both lenses (England 2005; Reskin 1993; Ridgeway and Correll 2004a).

\section{Supply Side Explanations}

A vast literature argues that gender socialization heavily influences occupational aspirations. According to socialization theory, socially constructed differences in values and thought processes guide women into occupations within the traditional feminine sphere (Hull and Nelson 2000; Jacobs 1989; Reskin 1993). Gender socialization reinforces the importance of domestic and family responsibilities for women, which can prevent them from acquiring the skills necessary to enter into male dominated occupations (Hull and Nelson 2000). Feminine jobs typically pay below average wages, and the share of women in an occupation is one of the largest determinants of the gender wage gap (Boraas and Rodgers 2003; Reskin and Padavic 1994). With regard to career choice, gender socialization can have negative consequences for 
women: they are clustered in jobs that pay less to begin with and they earn less than men working in the same occupations.

Human capital theory has also been applied to explain differential labor market outcomes. Early human capital theory argued that women invest less time than men in acquiring education, skills, and job training, which places them into lower paying and less prestigious jobs (Becker 1985). However, recent work finds that women's human capital investment rivals that of men, which is evidenced by the fact that the proportion of women in management positions has increased from one-third to almost one-half over the last 20 years (Cohen 2007). Despite the similarity in men's and women's human capital, gender negatively influences returns on salary and upward mobility for women. Smith finds that "investments in human capital attributes appear to enhance the authority chance of both men and women, but men receive a much higher authority return than women for possessing similar levels of human capital" (2002:531). While many studies of workplace gender inequality examine the effects of human capital, it is less salient in legal professions where the investment of men and women is virtually identical (Dixon and Seron 1995; Podmore and Spencer 1982; Wood, Corcoran, and Courant 1993).

\section{Demand Side Explanations}

One of the most popular explanations of occupational gender inequality is employer discrimination, which assumes many forms including statistical discrimination, homosocial reproduction, and bottom-up ascription. Statistical discrimination takes place when employers screen individuals by applying assumptions about the sexes_-including averages from formal and informal data - to predict ability and productivity (England 2005; Reskin 1993). Statistical discrimination occurs because individual measures of productivity are not accessible or are too expensive (England 2005), and it often contributes to the sex segregation of jobs-the most 
important cause of gender pay gaps (Boraas and Rodgers 2003; Reskin and Padavic 1994). Employers also discriminate by developing management enclaves composed of individuals who share common demographic characteristics (Kanter 1977). This homosocial reproduction leads to bottom-up ascription when employers seek to match subordinate groups on the basis of similar characteristics as a way to reduce perceptions of discrimination (Elliott and Smith 2001). Despite the external safeguards that suppress effects of discriminatory practices, like government policy and open information about reward structures (Ridgeway and Correll 2004a; Smith 2002), discrimination remains difficult to identify and curtail.

Another structural factor affecting women is their location within the labor market. Typically, men dominate the best occupations in manual and non-manual sectors while women are concentrated in marginalized economic sectors (Charles and Grusky 2004). This is the case in legal labor markets where women are disproportionately located in public law and are underrepresented in the remunerative private sector (Hull and Nelson 2000; Latourette 2005). Moreover, female-dominated occupations offer lower wages because they are culturally devalued (England et al. 2002), are less likely to offer positions of authority (Smith 2002), are located in lower-paying sectors (Tomaskovic-Devey 1993), and provide less job training (Tam 1997). The marginal positioning of women within the labor market ultimately contributes to the motherhood penalty (Budig and England 2001) and the sex gap in earnings (England 2005). Inequality in the Legal Profession

This thesis will apply both supply and demand perspectives in examining key factors identified in the literature as impeding women's progress in the legal profession. These factors include stereotyping and double standards, harassment and disparagement, insufficient mentoring, motherhood biases, tokenism, and sex segregation. These restraints contribute to several disparities in legal employment outcomes: relative to male associates, females earn less 
(Kay and Gorman 2008), are less likely to attain partnership (Beckman and Phillips 2005), and are given lower quality job assignments (Pierce 1995; Rosenberg et al. 1993).

Stereotyping and double standards. Gender stereotyping is one of several latent factors affecting the treatment and status of women lawyers. Viewing women in corporeal terms maintains the masculine character of the legal labor market (Thornton 1998). Male attorneys are often perceived as assertive litigators while females are characterized as "mothering" and better equipped to handle interpersonal work (Pierce 1995). As a corollary, women face a double standard and double bind as they are expected to maintain balance between assertiveness and softness while not appearing too aggressive or complaisant (Rhode 2002). Stereotypes and double standards in the legal profession create no-win situations for women, who are viewed as incapable of handling the stress of litigation but are too aggressive for collaboration and partnership (Epstein 1992). Stereotypes and double standards that are ingrained in the legal profession contribute to a negative work environment and women's restricted mobility on wage and authority hierarchies (Kay and Gorman 2008; Wilder 2007).

Harassment and disparagement. Two-thirds of women in the private sector and almost half of women in corporate and public law firms experience or observe sexual harassment from male partners, associates, or clientele (Laband and Lentz 1998). While there is no empirical evidence that sexual harassment affects earnings, women lawyers who experience harassment report lower job satisfaction and greater intention to quit (Laband and Lentz 1998). Disparagement in the form of demeaning comments, repeated interruption while speaking, and being addressed by terms of endearment undermines the stature of women lawyers in the eyes of clients, witnesses, and juries (Kay and Gorman 2008; Rosenberg et al.1993).

Mentoring. As a type of firm-specific human capital (Robson and Wallace 2001), mentoring is a significant predictor of the promotional opportunities and earnings potential of 
lawyers. Relationships with senior attorneys are crucial as they are the source of desirable job assignments, they provide substantive guidance on those assignments, and they supply career advice and connections (Dinovitzer et al. 2009). Women have inadequate access to mentoring and are often excluded from informal support networks in the practice (Rhode 2002; Wallace 2001). Male attorneys may be reluctant to mentor females because of sexual harassment concerns or because they enjoy bonding with male protégés, and female attorneys who are in the position to mentor are often overcommitted or do not want to risk being viewed negatively by their peers (Epstein 2001; Rhode 2002). Additionally, women lawyers who have male mentors report higher earnings but lower career satisfaction than women who have a female mentor (Wallace 2001).

Marital and motherhood status. Female attorneys who are married and or have children face significant disadvantages relative to their male counterparts. A woman's assumed domestic and familial responsibilities are frequently used as the rationale for discrimination (Podmore and Spencer 1982). While having a spouse and children is beneficial for male attorneys, it is detrimental for females (Hersch 2003). Although most firms have a maternity policy and "motherhood track" for women lawyers, the stigma associated with maternity leave discourages women from taking advantage of it (Epstein et al. 1995; Rhode 2002). Women who take time out of the labor force to care for their children are less likely to be promoted to partner, and mothers who attain partnership are paid significantly less than women who do not have children (Noonan and Corcoran 2004). This encourages women lawyers to delay childbearing or forgo it altogether (Cooney and Uhlenberg 1989; Dau-Schmidt et al. 2007).

Tokenism. Women have token status if they work in settings where fewer than 20 percent of their coworkers are female (Kanter 1977). Because token women are more visible, they may feel pressure to underachieve, and token female attorneys are more likely to be excluded from 
informal peer networks and be stuck in stereotypical roles (Kanter 1978). Although almost half of all law school students in the United States are women, the representation of women lawyers in the legal population is only about 31 percent (American Bar Association 2010). Women are especially likely to have token status in the private sector and in practice areas like corporate and criminal litigation. However, tokenism is most apparent in the upper echelons of the law, where only 6 percent of women are managing partners in the 200 largest law firms (American Bar Association 2011).

Sex segregation. Sector of employment has substantial bearing on the earnings potential of lawyers. Generally, corporate and criminal law is at the high end of the earnings spectrum and government and family law is at the low end. Historically, women lawyers have had their greatest opportunities in protected settings like government and family firms or in partnerships with their husbands (Kanter 1978). Although women today have gained entry into every legal sector, they remain overrepresented in less prestigious and less lucrative settings characterized by stereotypical gender roles, like family law and trusts and estates (Hull and Nelson 2000; Latourette 2005). The concentration of women in these sectors and practice areas is a powerful predictor of the gap in pay between men and women lawyers (Baker 2003; Dixon and Seron 1995).

\section{Employment Outcomes Associated with Gender Inequality in the Law}

The above mentioned supply and demand side factors contribute to a substantial gender disparity in earnings, the underrepresentation of women in partnership ranks, and the assigning of women to lower quality casework. Of the many negative outcomes attributed to gender inequality, the most thoroughly studied is the pay gap. According to current national estimates, women lawyers earn about 25 percent less than men per week (American Bar Association 2011). Finding that human capital investment of men and women lawyers is essentially identical 
(Dixon and Seron 1995; Podmore and Spencer 1982; Wood et al. 1993), researchers have sought to test other factors. As noted earlier, a key determinant of the legal gender pay gap is women's location within the labor market. Women tend to pursue less prestigious and lower paying jobs in the public sector and are more likely to work in firms with fewer attorneys. Moreover, women may struggle to meet billable hour requirements because they are given less complex job assignments, which negatively affects their pay (Dinovitzer et al. 2009).

Women are also significantly less likely than men to become partner, and those who are promoted to partnership earn less than their male counterparts (Angel et al. 2010; Gorman and Kmec 2009). Although the rising number of women lawyers suggests they no longer have token status, women remain concentrated in subordinate positions within the practice. In 2007, 45 percent of women were associates but only 18 percent were partners in large firms (Association for Legal Career Professionals 2007). It has been assumed that the underrepresentation of women in partnership positions is a pipeline issue, which will resolve itself as more women enter and advance in the profession. However, "this theory has had time to run its course and fails to explain the differences in numbers of men and women at the top of law firms" (Women Lawyers of Utah 2010:18).

Along with less monetary compensation and fewer opportunities for promotion, women lawyers are generally offered less challenging and less impactful job assignments than their male counterparts (Epstein 1992; Kay and Hagan 2003; Pierce 1995; Rosenberg et al. 1993). Some theories suggest that superiors consciously or subconsciously use gender as the rationale for offering women less prestigious assignments. Traditional stereotypes about female attorneys include a low level of job commitment, lack of assertiveness and aggressiveness, and inability to cope in stressful situations. Although women have demonstrated their competence and abilities through high rates of law school graduation and bar admittance, they are still less likely than 
men to procure high quality work that generates billable hours. Working on lower quality assignments can lead to negative performance reports, less pay, and eventual dismissal from the practice.

Research Questions and Hypotheses

This thesis examines data from a large sample of Utah lawyers to address several fundamental questions raised in existing theory and research: (1) What is the magnitude of the disparity in earnings and job assignment quality between male and female attorneys? (2) To what extent does gender and motherhood status affect the equitable treatment of women lawyers? (3) Which supply and demand side explanations are most predictive of the disparity in earnings and assignment quality? The foregoing discussion of sociolegal research guides the formulation of the following hypotheses:

$\mathrm{H}_{1}$ : A significant gender gap exists in the earnings and job assignment quality of attorneys in the sample.

$\mathrm{H}_{2}$ : Both gender and motherhood status negatively affect the earnings and job assignment quality of women lawyers.

$\mathrm{H}_{3}$ : The gender gap in earnings and assignment quality can be attributed to both supply and demand factors; employment sector (supply side) and discrimination (demand side) are the factors most predictive of the disparity.

\section{DATA AND METHODS}

The data come from the 2008-2009 Utah Attorney Advancement and Retention Survey (UAARS), a self-administered survey of all lawyers admitted to the bar from 1985 to 2005 in Utah. The Women Lawyers of Utah (WLU), in conjunction with the Utah State Bar Association, coordinated the survey. The response rate was 50 percent $(\mathrm{N}=2,668)$. Response bias cannot be estimated because the Utah State Bar Association is reticent to provide 
demographic information on the population of Utah bar members. Respondents who work in solo practices, academic fields, non-legal professions, or who are unemployed are excluded from the analyses. The analyses are further restricted to respondents who answered questions about earnings and assignment quality. The resulting base sample is 1,754 attorneys, of whom 578 (about 33 percent) are women.

The underlying focus of the UAARS is workplace equitability. Although the data are cross-sectional and do not measure conditions over time, the UAARS is one of only a handful of legal data sets that provides quantitative and open-ended data for important variables like discrimination, mentoring, tokenism, and motherhood status, which have seldom been simultaneously examined in past research. Moreover, existing sociolegal work has provided a segmented view of gender inequality among lawyers. While legal ethnographies focus on women's experiences in male dominated firms, quantitative research utilizes survey data to estimate the effects of predictors like employment sector, mentoring, and hours billed on outcomes like compensation. However, very few legal studies have been able to enhance quantitative findings with an analysis of open-ended responses. Thus, the UAARS data allow for a nuanced analysis of gender inequality in the Utah legal market.

\section{Outcome Variables}

The analyses focus on two key indicators of workplace equitability-earnings and assignment quality. Descriptive statistics for these variables are displayed in the upper panel of Table 1. The UAARS measures earnings by asking respondents, "About how much was your total job-related income in 2007? (Include your salary, bonuses, and profit sharing-any earnings/income from your job)." Responses range from "less than $\$ 400,000$ " to " $\$ 500,000$ or 
more." 2 Assignment quality is measured with a five-category item asking respondents, "How would you rate the quality of projects or assignments you normally work on relative to the projects given to your peers?" Responses range from "much lower quality" to "much higher quality." Only four percent of respondents indicated they received "lower quality" assignments and less than one percent indicated they received "much lower quality." Consequently, the assignment quality variable was collapsed into a binary measure coded 0 for "equal or lower quality" and 1 for "higher quality." The cases with missing data for earnings (13 percent) and assignment quality (six percent) are excluded from the analyses. ${ }^{3}$

\section{Explanatory Variables}

The regression models contain multiple variables that are empirically linked to gender inequality in the legal profession. These include discrimination, harassment, mentoring, parental status, tokenism, and employment sector. Descriptive statistics for these variables are presented in the middle panel of Table 1 .

Discrimination. This variable is measured dichotomously. Respondents were first asked if they had been treated unfairly in any significant way. They were then asked, "Did any of these situations become serious enough that you felt you were being discriminated against?" "Yes" responses are coded 1 and "no" responses are coded 0.

Harassment. This variable is measured dichotomously. Respondents were first asked if they had experienced situations where a coworker's, employer's, or client's verbal or physical behavior created an unpleasant or offensive work environment for them. Respondents who answered "yes" were then asked, "Did any of these situations become serious enough that you felt you were being harassed." "Yes" responses are coded 1 and "no" responses are coded 0.

\footnotetext{
${ }^{2}$ Although the categories are not all equidistant, a kernel density plot of earnings reveals the variable is virtually normally distributed; therefore, it is treated as a continuous variable for analytical purposes.

${ }^{3}$ Descriptive statistics and $t$-tests found negligible differences between the characteristics of the missing cases and the rest of the sample. Therefore, little or no bias is introduced into the analyses by excluding these cases.
} 
Mentoring. This variable is measured continuously. Respondents were asked to indicate the total number of mentors they had over the span of their legal career. This measure is used to compare the effects of mentoring on the earnings and assignment quality of lawyers who have been mentored versus those who have not. However, the continuous nature of this variable allows for an estimation of the effect of mentoring on the outcome variables for each additional mentor an attorney has had.

Parental status. This variable is measured continuously. Respondents were asked to indicate the total number of children (including biological, adopted, foster, or step) they have. This variable is used to determine whether a motherhood penalty exists. Furthermore, the continuous nature of the variable allows for an estimation of the extent of the penalty for each additional child a mother or father has.

Tokenism. This variable is based on a composite of the following two UAARS questions: (1) "In total, how many female attorneys work in the firm's office where you work?" and (2) "In total, how many attorneys does your firm currently employ?" A measure of the percentage of females who work in an office was created by dividing the number of female lawyers in the office by the total number of attorneys in the office. In keeping with previous research, women are considered token if they work in offices where fewer than 20 percent of the lawyers are female (Kanter 1978; Rosenberg et al. 1993).

Employment sector. This is a nominal variable. Respondents were asked to choose from a list that best describes their current employment position. Response categories include "law firm," "government," "company (in-house counsel)," and "non-profit organization." Dummy variables were created for each response option $(1=$ in the sector, $0=$ all others $)$ with "law firm" designated as the reference category. 


\section{Control Variables}

The regressions control for a range of individual and occupational characteristics including marital status, religion, hours billed, job tenure, firm size, has female superior, age, and bar admittance. Given the homogeneity of the sample (94 percent white), race is not included in the analyses. Marital status is a dichotomous variable coded 1 if the respondent is married and 0 if they are not. Religion is also dichotomous, coded 1 if the respondent is LDS and 0 if they are not. Hours billed is a continuous variable that measures the number of hours the respondent works in an average week. Job tenure is also a continuous variable that measures the number of years the respondent has worked at their current job. Firm size is measured continuously in terms of the number of attorneys employed at the respondent's firm. Has female superior is a dichotomous variable coded 1 if the respondent works under a female superior and 0 if they do not. Age is measured with a five-category variable $(1=29$ or younger, $2=30-39,3=40-49,4=$ $50-59,5=60$ or older). Dummy variables were created with "30-39" designated as the reference category. Bar admittance is measured with an item that asked respondents to indicate when they were admitted to the Utah bar $(1=1985-1989,2=1990-1994,3=1995-1999,4=2000-2005)$. Dummy variables were created with "2000-2005" designated as the reference category. Descriptive statistics for these variables are displayed in the lower panel of Table 1.

\section{Quantitative Analyses}

Prior to regression analyses, descriptive statistics are employed to illustrate differences between men and women in the sample. The data are then analyzed using a series of regression models in STATA. First, earnings are regressed on explanatory and control variables using linear (OLS) regression. Baseline (model 1), nested (model 2), full (model 3), and interaction terms (model 4) models are estimated and coefficients are presented in Table 2. Next, assignment quality is regressed on explanatory and control variables using logistic regression. 
Odds ratios from the baseline (model 1), nested (model 2), and full (model 3) models are presented in Table 3. For ease of interpretation, gender-specific models ( $3 a$ and $3 b$ ) are also presented in Table 3.

Missing data. The explanatory and control variables contain relatively few missing observations. The variables with the most missing observations are has female superior and hours billed, at two percent each. Missing data for the remaining variables is at one percent or less. Following Royston (2004), multiple imputation is used to estimate values for the missing data in the explanatory and control variables. Common techniques for dealing with missing observations, like mean substitution or listwise deletion, may bias analyses and produce misleading inferences. Rubin (1987) argues that multiple imputation is a more accurate method. Multiple imputation creates several imputed data sets for a data set with missing values. The analysis of a statistical model is then performed on each data set, and the analyses are aggregated to yield a set of results (Royston 2004). By accounting for the error of variance in the imputed values, multiple imputation provides reliable estimates for missing observations (Dow and Eff 2009).

\section{Open-Ended Response Analysis}

Whereas the goal of the quantitative analysis is to determine the extent of the gender gap in pay and assignment quality, the purpose of the open-ended analysis is to enhance the quantitative findings by providing insight as to the meaning behind the survey responses. To this end, the following open-ended UAARS items are analyzed: (1) "How have you been treated unfairly?" (2) "What happened to cause you to feel you were being discriminated against?" (3) "What do you feel is the primary reason you are given different quality of projects than your peers?" (4) "What is the primary reason why you feel you are not given assignments appropriate for your level of expertise?" 
After the data files were organized by question number and gender, the data were separated categorically for comparative purposes. The findings of the quantitative analyses dictate which respondents' open-ended responses merit examination; variables of interest include discrimination, mentoring, parental status, and employment sector. Analyzing the responses in this way provides valuable insight into the mechanisms that perpetuate gender inequality.

Initial codes were formed after careful reading and note-taking. Given the conceptual complexity of gender inequality, manifest coding was employed to identify overarching themes in the data. ${ }^{4}$ In this analysis, typical themes related to gender inequality included discrimination and harassment. After overarching themes were identified, a list of significant statements was extracted and grouped into meaning units. Following the coding, memoing, and analysis of these responses, themes and patterns were highlighted for presentation. Consistent with Creswell's (2007) suggestion for presenting qualitative research, findings are displayed in pertinent quotations and explanatory paragraphs. By examining how discrimination shapes the experiences and opportunities of the respondents, the open-ended response analysis provides greater depth of understanding into gender inequality among Utah lawyers.

\section{RESULTS}

\section{Quantitative Analyses}

Table 1 presents the descriptive statistics for all variables in the analyses. As expected, women report lower earnings and lower job assignment quality than men. While mean earnings for men are between $\$ 100,000$ and $\$ 125,000$, the mean for women is one category lower at $\$ 80,000$ to $\$ 100,000(p<.001)$. Earnings for the average woman are about one-half standard

\footnotetext{
${ }^{4}$ Whereas latent coding, or the identification of words associated with the concept of interest, would compromise the validity of the analysis, manifest coding increases the validity.
} 
deviation behind earnings for the average man, despite the fact that women are employed at larger firms which are typically more lucrative (Heinz et al. 2005; Wallace and Kay 2009). Fewer women than men also report that they receive higher quality job assignments than their peers $(p<.001)$. The gaps in pay and assignment quality are consistent with previously cited research which found that women earn less and are given lower quality casework than men (Chiu and Leicht 1999; Dinovitzer et al. 2009; Epstein 1992; Hersch 2003; Kay and Hagan 2003; Noonan et al. 2005; Pierce 1995; Rosenberg et al. 1993).

\section{[TABLE 1 ABOUT HERE]}

There are also noteworthy differences between men and women for several individual and structural variables. The data suggest that women are more likely than men to delay marriage and childbearing; ninety-three percent of men are married compared to only 69 percent of women $(p<.001)$, and the average woman has half as many children as the average man $(p<.001)$. These figures are not surprising, given findings from past work that female attorneys with children are paid less and are not as likely to be promoted to partnership as their male colleagues.

The data also reveal that the Utah legal market is sex-segregated to some degree. Although almost half of the women in the sample work in law firms, higher proportions of women are located in government and non-profit sectors than men $(p<.001)$. Women are also more likely to work in settings with higher percentages of female attorneys; on average, women are employed in practices with about 23 percent $(p<.001)$ more female attorneys than the firms in which men work.

A final difference of note is that eleven percent of women perceive they experienced discrimination at work compared to only one percent of men $(p<.001)$. Similarly, 10 percent of women experienced harassment compared to only two percent of men $(p<.001)$. There is no 
significant difference between men and women in terms of the mean number of mentors, tenure at current job, or year of Utah bar admittance.

\section{Linear Regressions}

Model 1. The baseline model estimates the effect of gender on earnings. As hypothesized, female attorneys earn significantly less than male attorneys $(p<.001)$.

Model 2. The nested model tests relationships between explanatory variables that are linked to the gender gap in pay. Factors that are predictive of higher pay include experiencing harassment, having more mentors, and having more children. Interestingly, lawyers who experience harassment are predicted to make more money than those who do not $(p<.05)$. Also, mean earnings are expected to increase moderately as attorneys gain mentors and have additional children $(p<.001)$. Factors associated with lower compensation include being female and employment in government or non-profit sectors of the profession relative to employment in law firms. In all, the explanatory variables in model 2 account for about one-third of gender's effect on earnings.

\section{[TABLE 2 ABOUT HERE]}

Model 3. The full model incorporates the remaining controls into the regression. After accounting for all the variables in the model, gender differences in earnings remain. The magnitude of this disparity is likely compounded when considered over the span of an entire career. Factors that are predictive of higher pay include having more mentors, billing more hours, having longer tenure, working in larger firms, being between the ages of 40 and 59 , and being admitted to the bar between 1985 and 1999. Each of these variables has a modest effect on earnings, with the exception of admittance to the bar between 1985 and 1989, which has the single largest positive effect of all the variables tested. Mean earnings for attorneys who were 
admitted to the bar between 1985 and 1989 are expected to be higher than the earnings of attorneys who were admitted between 2000 and $2005(p<.001)$.

Factors associated with lower compensation include being female, employment in government or non-profit sectors relative to working in law firms, and being LDS. As hypothesized, employment sector has a considerable impact on pay. Working in government and non-profit organizations has the largest negative effect on earnings of all the variables tested. Mean earnings of government attorneys are predicted to be 2.1 units $(p<.001)$ lower than those of law firm attorneys, and earnings of non-profit attorneys are expected to be 2.7 units $(p<.001)$ lower than those of law firm attorneys. The explanatory and control variables in the full model explain about half of gender's effect on earnings.

Contrary to expectations, the measure for tokenism, percent females at job, has no effect on earnings. This does not substantiate Kanter's (1977) theory of tokenism which argues that a woman who works in a setting where she is considered token is more likely to experience inequality. While discriminatory behavior may manifest itself in a variety of ways, model 3 suggests token women lawyers in the sample are not openly discriminated against with regard to compensation.

Model 4. Model 4 introduces interaction terms to understand how the effects of certain factors differ by gender. There are no statistically significant differences between men and women in terms of marital status, hours billed, mentoring, discrimination, or harassment. As hypothesized, a substantial motherhood penalty contributes to the gender pay gap. For every additional child a woman has, her mean earnings are predicted to decrease by .274 units $(p<$ .001) relative to men. This lends empirical support to the large body of research regarding the negative effects of motherhood on women in the workplace (Budig and England 2001; Hersch 2003; Noonan and Corcoran 2004; Ridgeway and Correll 2004b). Additionally, women who 
work in government and non-profit sectors earn more on average than their male counterparts in the same sectors $(p<.05)$.

\section{Logistic Regressions}

Model 1. The baseline model tests the relationship between gender and the likelihood of working on higher quality projects than one's peers. As anticipated, women are less likely to procure higher quality assignments. The odds that women receive higher quality assignments are 37 percent $(p<.001)$ lower than the odds that men receive higher quality assignments.

\section{[TABLE 3 ABOUT HERE]}

Model 2. The nested model controls for the effects of the explanatory variables. After statistically adjusting for the explanatory variables, women are 34 percent $(p<.001)$ less likely than men to receive higher quality assignments. The odds of a lawyer working on higher quality assignments increase by six percent $(p<.05)$ with each mentor they have. Attorneys in the government sector are 38 percent $(p<.001)$ less likely than attorneys in law firms to receive higher quality work than their peers.

Model 3. The full model combines explanatory and control variables to estimate the likelihood of receiving higher quality assignments. Women are 25 percent $(p<.05)$ less likely than men to be given higher quality assignments. The odds that government lawyers have higher quality projects are about 32 percent $(p<.01)$ lower than the odds that law firm lawyers have higher quality projects. Each additional hour billed and year of tenure is associated with a four percent increase in the likelihood of receiving higher quality projects. Lawyers who were admitted to the bar between 1985 and 1989 are 74 percent $(p<.05)$ as likely to work on higher quality assignments as lawyers who were admitted between 2000 and 2005 .

Model 3a. Factors significantly affecting the quality of projects men receive include the percentage of women at their practice, hours billed, tenure at current job, and being 29 or 
younger. Men who work in practices with greater numbers of women are slightly less likely to report working on higher quality assignments $(p<.05)$. Each additional hour billed by a man is associated with a four percent $(p<.001)$ increase in the odds that they receive higher quality assignments, and each year of tenure is associated with a three percent $(p<.05)$ increase in the odds that men receive higher quality assignments. Men age 29 or younger are almost three times $(p<.05)$ as likely to receive high quality projects as men between the ages of 30 and 39.

Model $3 b$. Factors significantly affecting the quality of projects women receive include experiencing discrimination, working in the government sector, billing more hours, and passing the bar between 1985 and 1989. For women, year of bar admittance has the single largest effect on the likelihood of receiving higher quality work. Women who passed the bar between 1985 and 1989 are 3.7 times $(p<.001)$ as likely to procure higher quality work assignments as women who passed the bar between 2000 and 2005. Women who experienced discrimination are more than two times $(p<.05)$ as likely to be given higher quality work as women who did not experience discrimination. Women who are employed in the government sector are 51 percent $(p<.001)$ less likely to receive high quality work compared to women in law firms. Each additional hour billed by a woman is associated with a three percent $(p<.01)$ increase in the odds that she receives higher quality assignments than her peers.

The most notable differences in the coefficients of men and women are between the following factors: experiencing discrimination, working in the government sector, being 29 or younger, and passing the bar between 1985 and 1989. Interactions with gender and each of these variables reveal that the only statistically significant differences in receiving higher quality assignments between men and women are for lawyers aged 29 or younger and lawyers admitted to the bar between 1985 and 1989 . 


\section{Open-Ended Response Analysis}

After accounting for a wide range of measures associated with gender inequality in the legal profession, an unexplained gap remains in the earnings and job assignment quality of men and women lawyers in Utah. Typically, researchers attribute the unexplained portion of persistent gender gaps to discrimination (Dinovitzer et al. 2009). Yet, contrary to expectations, discrimination did not negatively affect either outcome variable in the quantitative analyses. In fact, only 11 percent of women in the sample report experiencing discrimination at work. One explanation for the analytical insignificance of discrimination is simply that it may be vanishing with the increasing - albeit gradual-feminization of the legal profession in Utah. Now more than ever, "Women's representation in law far surpasses the token numbers of the 1970s, with women making inroads to all sectors of practice, elite firm partnerships, the bench, and governance of the bar" (Kay and Gorman 2008:300). With the increased visibility of women attorneys, it is plausible that the legal profession has become more egalitarian and fewer women experience discrimination today. This may be evidenced by the insignificance of tokenism in the regression analyses.

While it is likely that discriminatory behavior in the firm has abated, statements from the open-ended responses suggest it still shapes expectations and opportunities for women more so than men. Only 17 of the 1,176 men in the sample report encountering discrimination at work. These men identify age, marital status, and religion as the basis for the unfair treatment. Their experiences were mostly situational and there is no discernable overarching theme among the responses.

As expected, more women than men report experiencing inequitable treatment at work; 11 percent of women experienced discrimination compared to only one percent of men. The overwhelming majority of women who responded state that discrimination was based primarily 
on sex, and distinct patterns of blatant and subtle discrimination emerge from their responses.

The most common form of blatant discrimination cited by women is differential compensation:

I received the same amount of bonus as a male attorney with less seniority, less collections and less origination credits. I see that happen to other female attorneys.

[A male colleague] has been given over $\$ 20,000$ in pay raises in five years whereas I have received \$10,000. I have completed the work assignments and received favorable evaluations. . . . Other people in my company have said that male co-workers have received pay raises whereas their female counterparts have not, or are not paid at the same level.

The pay gap is one of the most perceptible manifestations of occupational gender inequality. While regression analysis identified the extent of the pay gap in Utah practices, comments like those above indicate that bonus money and pay raises may play a key role in contributing to the disparity. These statements suggest that while salary is the traditional variable of interest in pay gap research, salary alone may be a deficient measure of lawyers' earnings and should not be relied upon to accurately quantify the legal pay gap.

Although several women convey instances of blatant inequality like unequal pay, the central theme in most responses is subtle, sex-based discrimination. This is consistent with other research that found indirect and structural discrimination has taken the place of overt discrimination in the firm (Epstein 2001; Kay and Gorman 2008). The complex and often imperceptible nature of gender discrimination in the law renders it difficult to observe and measure. Nevertheless, women's responses suggest that discrimination may be rooted in the legal profession's culture of male dominance, as one woman noted:

It is obvious that males just run the show. That's the reality - live with it or leave.

The dominance of men, especially in the remunerative private sector and in partnership ranks, has cultivated a "good old boys" network in most practices. Inclusion in this network is crucial for success, especially in establishing and sustaining relationships with colleagues and clientele. 
For some women, exclusion creates challenges that may ultimately stall their advancement by diminishing their work load:

When others (males) have a drop in their case loads, the firm (it appears) rallies behind them to get them some work to keep up their hours and collections. When my work load dropped I was left to fend completely for myself.

Additionally, the exclusion of women from networks in the firm can perpetuate traditional gender stereotypes and subtle discrimination from clients:

I have often made several hour-long presentations to groups of prospective clients, in which I quoted federal statutes off the top of my head, was generally brilliant, and then was told that the group (of men) wanted to meet with a "real attorney," meaning a man.

Despite women's increased presence, assumptions about gender remain deeply embedded in the structure of the legal profession. Stereotypes regarding women in the law suggest marriage and family responsibilities are detrimental to their professional competence and investment in the firm (Podmore and Spencer 1982). These beliefs contribute to the differential treatment of women, including lower pay and less support from superiors:

Because my husband makes money, I believe that it is perceived that I do not need to make as much as some of my male colleagues.

Boss issued performance report and decoration inconsistent with my historical awards and awards of my peers. . . . because he (single, middle-aged man) was having a more "close" relationship with a more senior (female) attorney. . . In his mind he could only pick one woman to support and I was already married.

Gender beliefs also tend to channel women lawyers into "desk-bound" assignments like conveyance, wills and probate, and matrimonial work (Podmore and Spencer 1982). Some women lawyers may even be relegated to paralegal or secretarial responsibilities:

[I receive] less pay, more work, and some secretarial duties. Can't always go to lunch with "the boys" because I need to answer phones.

The open-ended responses shed light on another subtle way in which women face inequitable treatment: opportunity paths and structures are strikingly different for men than they are for women. In the legal profession, men are presumed to be capable whereas women must 
demonstrate their capability, and men are evaluated on potential while women are judged by achievement (Women Lawyers of Utah 2010). When asked why they receive different quality assignments than their peers, men's responses reveal a much different perception of how success is achieved than those of women. Overall patterns for men indicate that they associate receiving quality casework with having a proven track record, seniority and experience, or being a partner. Essentially, most men believe following the traditional career path of a lawyer will yield quality casework, which can translate into more billable hours, higher wages, and eventual partnership.

On the other hand, women's responses suggest they believe they must diverge from the traditional path in order to succeed in the profession. Responses yielded three recurring themes regarding women's propensity to have high quality assignments. First, many women attribute receiving quality assignments to developing an extraordinary work ethic:

Generally, I work harder and take extreme pride in producing a quality work product.

Because their performance is often scrutinized more harshly than men's, women may also feel the need to go above and beyond normal expectations to demonstrate their capability:

I take my role as an attorney more seriously than some of my peers. . . . I file my own petitions, when necessary, and involve myself more actively in the litigation portion of the job.

Second, women associate receiving quality casework with their ability to carve out a niche in their practice. A woman may reason that her chance of obtaining quality work is greater if she specializes in a unique practice area:

I have developed expertise in certain areas of the law that most attorneys in our firm do not have.

Third, women attribute receiving quality projects to building rapport with partners. Most women are at a disadvantage when they enter the profession because they lack access to the social networks needed to develop close relationships with colleagues and clients (Kay and 
Gorman 2008). While few men cite their relationship with partners as a factor affecting the quality of work they receive, many women believe it is critical:

Assignments are given by individual partners, based on their individual preferences. I have established rapport with partners whose practice areas I enjoy and work well with them. Other associates have not done one or both of these things.

Opportunity paths and structures are markedly different for men and women. Whereas men associate receiving quality assignments with having a proven track record, seniority and experience, or being a partner, women attribute receiving quality assignments to an extraordinary work ethic, narrow specialization, and building rapport with partners.

There are many subtle discriminatory barriers that stall women's advancement in the legal profession. Given the small number of women in the sample who report experiencing discrimination, it is not surprising that it had no effect in the regression analyses. However, the open-ended responses suggest gender discrimination in the Utah legal market is far from insignificant. Rather than disappearing altogether, discrimination has merely become less perceptible. While encounters with subtle discrimination can still give women the impression that they are not being treated equally, they may not associate these experiences with an ominous term like discrimination. Perhaps this is why so few women in the sample report experiencing discrimination - they may have experienced subtle discrimination without defining it as such.

\section{DISCUSSION}

At the latter end of the 19th century, Myra Bradwell became the first woman to gain admittance to a state bar in the United States (Friedman 1993). Since that time, women have made steady progress in the profession. Still, women face many obstacles to their advancement. The purpose of this thesis was to examine gender inequality in the Utah legal market. By so doing, it extends the sociolegal literature in three important ways. First, it provides 
documentation of the position of women in a legal market characterized by paternalistic norms and slow feminization. Past research has disproportionately focused on the advancement of female attorneys in larger, less conservative legal markets. Second, the analyses include a wide range of variables that have rarely been simultaneously examined in previous work. Moreover, this thesis joins only a handful of legal studies in providing a nuanced view of gender inequality by utilizing quantitative and open-ended analyses. Third, this thesis demonstrates the need for refining measures of discrimination in the law. Better measures are needed to capture the effect of subtle discrimination, which may account for a portion of the gender gap that remains unexplained by traditional variables.

\section{Inequality in the Utah Legal Market}

Despite the uniqueness of the Utah context, many of my findings are consistent with research in other legal markets. I first tested the hypothesis that a significant gender gap exists in the earnings and assignment quality of Utah attorneys. Regression analyses affirmed that on average, female attorneys earned significantly less than males in 2007 , even after controlling for numerous individual and structural factors. I also found that women are less likely than men to procure higher quality assignments than their colleagues. The existence of these gender gaps is not unique to Utah; previous work has identified disparities in earnings (Chiu and Leicht 1999; Dinovitzer, Reichman, and Sterling 2009; Hersch 2003; Noonan, Corcoran, and Courant 2005) and job assignment quality (Epstein 1992; Kay and Hagan 2003; Pierce 1995; Rosenberg, Perlstadt, and Phillips 1993) in a variety of legal markets.

I then tested the hypothesis that gender and motherhood status negatively affect women's pay and job assignment quality. Consistent with theory and the seminal research of Ridgeway and Correll (2004b) and Budig and England (2001), I found that demand side employer bias operates against women and mothers in Utah. Regression analysis revealed 
women's earnings are expected to be lower than men's, and women are less likely to be given high quality assignments. There is also a motherhood penalty where mothers' earnings are predicted to significantly decrease with every additional child they have. The negative effect of gender and motherhood remained even after controlling for employment sector and hours billed - two popular explanations for why women lawyers earn less than men. Furthermore, open-ended responses suggest women are given lower status than men, which is evidenced by their exclusion from networks within the firm, their assignment to work based on traditional gender roles, and their more arduous path to success. Similar gender and motherhood biases have been documented in other legal markets (Hersch 2003; Noonan and Corcoran 2004).

To test my third and final hypothesis, I examined relationships between multiple supply and demand side variables. Results provided mixed support for the hypothesis. As expected, the supply factor most predictive of unequal pay and job assignments is the sector of employment attorneys choose to work in. As is the case in other legal markets (Hull and Nelson 2000; Latourette 2005), a higher proportion of Utah women are employed in the government and nonprofit sector than men. Attorneys in these sectors earn less and are more likely to receive lower quality job assignments. These findings support theories regarding the negative implications of sex segregation for women in the labor market (England 2005; Jacobs 1989; Reskin 1993). However, contrary to my third hypothesis, regression analyses did not find the demand side discrimination variable to negatively affect pay or assignment quality. The variables in the analyses accounted for one-half of the gender gap in pay and about one-third of the gender gap in assignment quality, leaving a considerable portion of the disparities unexplained. Although the close-ended measure for discrimination had no statistically significant effect, the open-ended responses suggest at least some of the unexplained variance may be attributable to subtle discrimination. Women's responses reveal that discrimination in the Utah legal market is likely 
to be manifest as subtle attitudes and behaviors including a culture of male dominance, exclusion from the "good old boys" network, perpetuation of traditional gender roles and stereotypes, and differential opportunity paths and structures.

Whereas several of my findings substantiate existing theory and research, others do not. Perhaps most notably, I find no support for Kanter's theory of tokenism in the Utah legal market, as being employed in a firm where fewer than 20 percent of the attorneys are women has no effect on pay or assignment quality. Moreover, studies in other settings have found marital status, mentoring, firm size, and hours billed to be important predictors of employment outcomes for women. My analyses find these factors to have little or no effect on the pay or assignment quality of women lawyers in Utah. While Utah women might be making progress toward equitability in terms of these variables, they still face challenges in the form of sex segregation, the motherhood penalty, and subtle discrimination.

\section{Limitations}

Discrimination is a key factor of interest in most studies of occupational gender inequality. Unfortunately, it is also one of the most difficult variables to comprehensively measure. Although I sought to control for the effects of discrimination in my quantitative analyses, the item used to measure it in the UAARS is insufficient. Like many measures of discrimination before it, the variable I used focuses more on front stage instances of discrimination rather than back stage attitudes and expectations. The open-ended responses suggest tacit discrimination may be responsible for a portion of the unexplained variance in persistent gender gaps in the legal profession. Ideally, research should test both explicit and implicit forms of discrimination rather than only the situations that "become serious enough," or perceptible enough, to be considered discriminatory. 
Another limitation is the less-than-ideal measurement of the two outcome variables. The UAARS measures earnings categorically so as to preserve the anonymity of the respondent. Although categorical measures of income are typically less intrusive and may increase response rate, they also provide less precise quantifications of the pay gap. Also, the close-ended question regarding job assignment quality in the UAARS does not clearly specify the reference group to which respondents compare their quality of work. The question uses the generic term peers without differentiating between men and women, or lawyers within or outside the practice group. The findings should be interpreted with these measurement limitations in mind.

\section{Implications for Future Research}

Given that occupational gender discrimination has shifted from blatant to subtle forms, we should rethink the way we conceptualize and measure inequitable treatment in the law. I suspect women lawyers are less likely to report experiencing discrimination because of its tacit nature. While there is value in controlling for blatant discrimination in the form of specific instances of unfair treatment, it is perhaps even more critical to investigate the role firm culture, attitudes, and expectations play in maintaining gender gaps. Therefore, I submit that future studies would benefit from the use of conscientiously defined measures of overt and subtle discrimination. In particular, measures of discrimination should seek to capture the differential trajectories for success of men and women lawyers. Using refined measures of discrimination will provide a more accurate depiction of women's position in the profession while minimizing the persistent unexplained portion of the gender gap.

Additionally, much of what is known about gender inequality in the legal profession is based on studies of lawyers in Canada, Chicago, and Los Angeles. More research is needed in small, conservative legal markets. Have female attorneys in these settings achieved the same level of equitability as women in other markets? Future research should compare employment 
outcomes such as earnings, assignments, and promotion between women and men in a greater variety of markets so as to ascertain whether and to what extent a disparity exists. To my knowledge, this is an avenue that has not been sufficiently explored by present research.

Finally, future research should carefully consider the influence methodology can have on results. Whereas quantitative analyses implicated employment sector as perhaps the most important predictor of the gender gap in pay and assignment quality, open-ended analysis revealed that discrimination - which had no statistical effect on either outcome variable-may still play an important role in determining employment outcomes for men and women lawyers. Because it is difficult to capture the subtle nuances of gender inequality with quantitative data alone, forthcoming research should seek to employ a mixed-methods approach. 


\section{References}

American Bar Association. 2010. “Goal III Report Card: An Annual Report on Women's Advancement into Leadership Positions in the American Bar Association." Retrieved November 3, 2010 (http://www.abanet.org/women/goalix/2010goal_iii_women.pdf).

—. 2011. "A Current Glance at Women in the Law." Retrieved May 26, 2011 (http://www.americanbar.org/content/dam/aba/uncategorized/2011/cwp_current_gla nce_statistics_2011.authcheckdam.pdf).

Angel, Marina, Eun-Young Whang, Rajiv D. Banker, and Joseph Lopez. 2010. "Statistical Evidence on the Gender Gap in Law Firm Partner Compensation.” Temple University Legal Studies Research Paper No. 2010-24. Retrieved April 25, 2011 (http://ssrn.com/abstract=1674630).

Association for Legal Career Professionals. 2007. "Minority Women Still Underrepresented in Law Firm Partnership Ranks - Change in Diversity of Law Firm Leadership Very Slow Overall." Washington, DC: NALP.

Baker, Joe G. 2003. "Glass Ceilings or Sticky Floors? A Model of High-Income Law Graduates." Journal of Labor Research 24:695-711.

Becker, Gary S. 1985. "Human Capital, Effort, and the Sexual Division of Labor." Journal of Labor Economics 3:33-58.

Beckman, Christine M. and Damon J. Phillips. 2005. "Interorganizational Determinants of Promotion: Client Leadership and the Attainment of Women Attorneys." American Sociological Review 70:678-701.

Bobbit-Zeher, Donna. 2007. "The Gender Income Gap and the Role of Education." Sociology of Education 80:1-22. 
Boraas, Stephanie and William M. Rodgers. 2003. "How Does Gender Play a Role in the Earnings Gap? An Update." Monthly Labor Review 126:9-15.

Budig, Michelle and Paula England. 2001. "The Wage Penalty for Motherhood." American Sociological Review 66:204-25.

Charles, Maria and David B. Grusky. 2004. Occupational Ghettos: The Worldwide Segregation of Women and Men. Stanford, CA: Stanford University Press.

Chiu, Charlotte and Kevin T. Leicht. 1999. "When Does Feminization Increase Equality? The Case of Lawyers." Law \& Society Review 33:557-93.

Coffey, Bentley and Patrick A. McLaughlin. 2009. "Do Masculine Names Help Female Lawyers Become Judges? Evidence from South Carolina." American Law and Economics Review 11:112-133.

Cohen, Philip N. 2007. "Working for the Woman? Female Managers and the Gender Wage Gap." American Sociological Review 72:681-704.

Cooney, Teresa M. and Peter Uhlenberg. 1989. "Family-Building Patterns of Professional Women: A Comparison of Lawyers, Physicians, and Postsecondary Teachers." Journal of Marriage and Family 51:749—58.

Creswell, John W. 2007. Qualitative Inquiry and Research Design: Choosing Among Five Approaches. Thousand Oaks, CA: Sage.

Dau-Schmidt, Kenneth G., Marc S. Galanter, Kaushik Mukhopadhaya, and Kathleen E. Hull. 2007. "Gender and the Legal Profession: The Michigan Alumni Data Set 1967-2000." Indiana Legal Studies Research Paper No. 104. Retrieved April 22, 2011 (http://papers.ssrn.com/sol3/papers.cfm?abstract_id=1017362). 
Dinovitzer, Ronit, Nancy Reichman, and Joyce Sterling. 2009. "The Differential Valuation of Women's Work: A New Look at the Gender Gap in Lawyers' Incomes." Social Forces 88:819-64.

Dixon, Jo and Carroll Seron. 1995. "Stratification in the Legal Profession: Sex, Sector, and Salary." Law and Society Review 29:381-412.

Dow, Malcom M. and E. Anthon Eff. 2009. "Multiple Imputation of Missing Data in CrossCultural Samples." Cross-Cultural Research 43:206-29.

Elliott, James R. and Ryan A. Smith. 2001. "Race, Gender, and Workplace Power." American Sociological Review 69:365-86.

England, Paula. 2005. "Gender Inequality in Labor Markets: The Role of Motherhood and Segregation." Social Politics: International Studies in Gender, State \& Society 12:264-88.

England, Paula, Michelle Budig, and Nancy Folbre. 2002. "Wages of Virtue: The Relative Pay of Care Work." Social Problems 49:455-73.

Epstein, Cynthia Fuchs. 1992. "Tinkerbells and Pinups: The Construction and Reconstruction of Gender Boundaries at Work." Pp. 232-56 in Cultivating Differences: Symbolic Boundaries and the Making of Inequality. Chicago, IL: University of Chicago Press.

— 2001. "Women in the Legal Profession at the Turn of the Twenty-First Century: Assessing Glass Ceilings and Open Doors." University of Kansas Law Review 49:733—53.

Epstein, Cynthia Fuchs, Robert Saute, Bonnie Oglensky, and Martha Gever. 1995. "Glass Ceilings and Open Doors: Women's Advancement in the Legal Profession." Fordham Law Review 64:291—449.

Friedman, Jane M. 1993. America's First Woman Lawyer: The Biography of Myra Bradwell. New York: Prometheus Books. 
Gorman, Elizabeth H. and Julie Kmec. 2009. "Hierarchical Rank and Women's Organizational Mobility: Glass Ceilings in Corporate Law Firms." American Journal of Sociology 114:1428-74.

Heinz, John P., Robert L. Nelson, Rebecca L. Sandefur, and Edward O. Laumann. 2005. Urban Lawyers: The New Social Structure of the Bar. Chicago, IL: University of Chicago Press.

Hersch, Joni. 2003. "The New Labor Market for Lawyers: Will Female Lawyers Still Earn Less?" Cordozo Women's Law Journal 10:1—58.

Huber, Joan. 2007. On the Origins of Gender Inequality. Boulder, CO: Paradigm.

Hull, Kathleen E. and Robert L. Nelson. 2000. "Assimilation, Choice, or Constraint? Testing Theories of Gender Differences in the Careers of Lawyers." Social Forces 79:229—64.

Jacobs, Jerry A. 1989. Revolving Doors: Sex Segregation and Women's Careers. Stanford, CA: Stanford University Press.

Jones, Jeffrey M. 2010. "Wyoming, Mississippi, Utah Rank as Most Conservative States." Retrieved June 24, 2011 (http://www.gallup.com/poll/141677/wyoming-mississippiutah-rank-conservative-states.aspx).

Kanter, Rosabeth Moss. 1977. Men and Women of the Corporation. New York: Basic Books.

—. 1978. "Reflections on Women and the Legal Profession: A Sociological Perspective." Harvard Women's Law Journal 1:1-17.

Kay, Fiona M. and John Hagan. 1998. "Raising the Bar: The Gender Stratification of LawFirm Capital." American Sociological Review 63:728-43.

— 2003. "Building Trust: Social Capital, Distributive Justice and Loyalty to the Firm." Law and Social Inquiry 28:483-519.

Kay, Fiona M. and Elizabeth H. Gorman. 2008. "Women in the Legal Profession." Annual Review of Law and Social Science 4:299-332. 
Laband, David N. and Bernard F. Lentz. 1998. "The Effects of Sexual Harassment on Job Satisfaction, Earnings, and Turnover among Female Lawyers." Industrial \& Labor Relations Review 51:594—607.

Latourette, Audrey Wolfson. 2005. "Sex Discrimination in the Legal Profession: Historical and Contemporary Perspectives." Valparaiso University Law Review 39:859—909.

Noonan, Mary C. and Mary E. Corcoran. 2004. "The Mommy Track and Partnership: Temporary Delay or Dead End?" Annals of the American Academy of Political and Social Science 596:130-50.

Noonan, Mary C., Mary E. Corcoran, and Paul N. Courant. 2005. "Pay Differences Among the Highly Trained: Cohort Differences in the Sex Gap in Lawyers' Earnings." Social Forces $84: 853-72$.

Padavic, Irene and Barbara F. Reskin. 2002. Women and Men at Work. Thousand Oaks, CA: Pine Forge Press.

Pierce, Jennifer L. 1995. Gender Trials: Emotional Lives in Contemporary Law Firms. Berkeley, CA: University of California Press.

Podmore, David and Anne Spencer. 1982. "Women Lawyers in England: The Experience of Inequality." Work and Occupations 9:337-61.

Reskin, Barbara F. 1993. "Sex Segregation in the Workplace." Annual Review of Sociology 19:241-70.

—. 2003. "Including Mechanisms in our Models of Ascriptive Inequality." American Sociological Review 68:1-21.

Reskin, Barbara F. and Patricia A. Roos. 1990. Job Queues, Gender Queues: Explaining Women's Inroads into Male Occupations. Philadelphia, PA: Temple University Press. 
Reskin, Barbara F. and Irene Padavic. 1994. Women and Men at Work. Thousand Oaks, CA: Pine Forge Press.

Rhode, Deborah. 1988. "Perspectives on Professional Women." Stanford Law Review 40:1163— 1207.

—. 2002. "Gender and the Profession: The No-Problem Problem." Hofstra Law Review 30:1001-14.

Ridgeway, Cecilia L. 1997. "Interaction and the Conservation of Gender Inequality: Considering Employment." American Sociological Review 62:218-35.

Ridgeway, Cecilia L. and Lynn Smith-Lovin. 1999. "The Gender System and Interaction." Annual Review of Sociology 5:191-216.

Ridgeway, Cecilia L. and Shelley J. Correll. 2004a. "Unpacking the Gender System: A Theoretical Perspective on Gender Beliefs and Social Relations." Gender and Society $18: 510-31$.

—. 2004b. "Motherhood as a Status Characteristic." Journal of Social Issues 60:683-700.

Robson, Karen and Jean E. Wallace. 2001. "Gendered Inequalities in Earnings: A Study of Canadian Lawyers." Canadian Review of Sociology 38:75-95.

Roos, Patricia A. and Barbara F. Reskin. 1984. "Institutional Factors Contributing to Sex Segregation in the Workplace." Pp. 234-60 in Sex Segregation in the Workplace: Trends, Explanations, Remedies. Washington, D.C.: National Academy Press.

Rosenberg, Janet, Harry Perlstadt, and William R.F. Phillips. 1993. "Now that we are here: Discrimination, Disparagement, and Harassment at Work and the Experience of Women Lawyers." Gender \& Society 7:415-33.

Royston, Patrick. 2004. "Multiple Imputation of Missing Values." The Stata Journal 4:227—41. 
Rubin, Donald B. 1987. Multiple Imputation for Nonresponse in Surveys. New York: John Wiley and Sons, Inc.

Smith, Ryan A. 2002. "Race, Gender, and Authority in the Workplace: Theory and Research." Annual Review of Sociology 28:509-42.

Tam, Tony. 1997. "Sex Segregation and Occupational Gender Inequality in the United States: Devaluation or Specialized Training?" American Journal of Sociology 201:1652-92.

Thornton, Margaret. 1998. "Authority and Corporeality: The Conundrum for Women in Law." Feminist Legal Studies 6:147-70.

Tomaskovic-Devey, Donald. 1993. Gender and Race Inequality at Work: The Sources and Consequences of Job Segregation. New York: ILR Press.

Wallace, Jean E. 2001. "The Benefits of Mentoring for Female Lawyers." Journal of Vocational Behavior 58:366-91.

Wallace, Jean E. and Fiona M. Kay. 2009. "Are Small Firms More Beautiful or is Bigger Better? A Study of Compensating Differentials and Law Firm Internal Labor Markets." Sociological Quarterly 50:474-96.

Wilder, Gita Z. 2007. "Women in the Profession: Findings from the First Wave of the After the JD Study." Washington, DC: NALP.

Women Lawyers of Utah. 2010. "The Utah Report: The Initiative on the Advancement and Retention of Women in Law Firms." Retrieved May 24, 2011 (http://utahwomenlawyers.org/wp-content/uploads/WLU_Report_Final.pdf).

Wood, Robert G., Mary E. Corcoran, and Paul N. Courant. 1993. "Pay Differences among the Highly Paid: The Male-Female Earnings Gap in Lawyers' Salaries." Journal of Labor Economics 11:417—41. 
TABLE 1. Descriptive Statistics, Utah Attorney Advancement and Retention Survey, 2008-2009

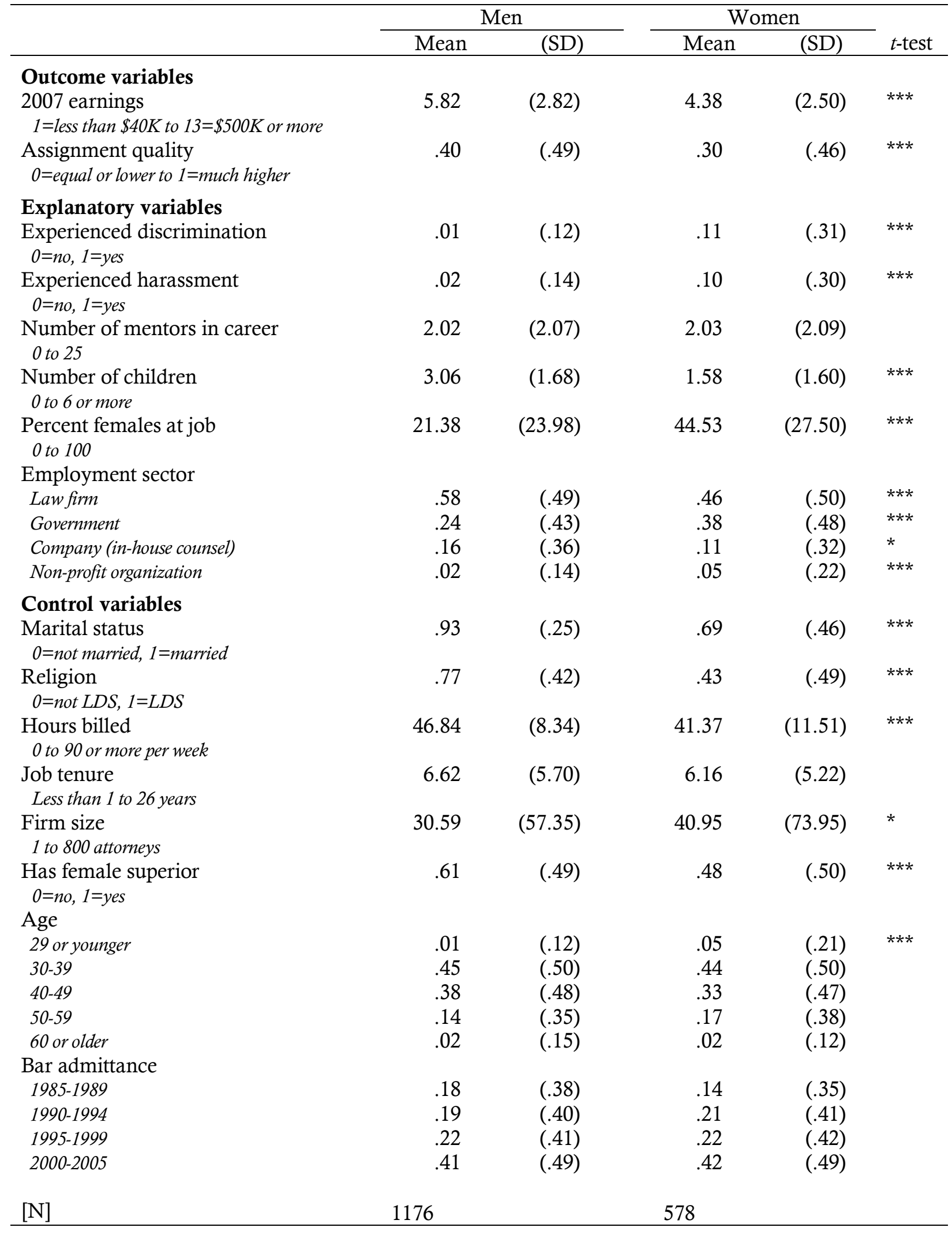

${ }^{*} p<.05,{ }^{* *} p<.01,{ }^{* * *} p<.001$ (two-tailed tests). 
TABLE 2. Linear Regressions of 2007 Earnings, Utah Attorney Advancement and Retention Survey, 2008-2009

\begin{tabular}{|c|c|c|c|c|}
\hline & Model 1 & Model 2 & Model 3 & Model 4 \\
\hline \multicolumn{5}{|l|}{ Explanatory variables } \\
\hline Female & $-1.441^{* * *}$ & $-.999 * * *$ & $-.728 * * *$ & -.374 \\
\hline Experienced discrimination & & -.023 & -.372 & -.373 \\
\hline Experienced harassment & & $.598^{*}$ & .163 & -.220 \\
\hline Number of mentors & & $.113^{* * *}$ & $.068^{* *}$ & .054 \\
\hline Number of children & & $.131^{* * *}$ & .072 & $.149^{* * *}$ \\
\hline Percent females at job & & .004 & -.000 & .004 \\
\hline \multicolumn{5}{|l|}{ Employment sector ${ }^{\mathrm{a}}$} \\
\hline Government & & $-2.091 * * *$ & $-2.114^{* * *}$ & $-2.386^{* * *}$ \\
\hline Company (in-house) & & .170 & $.357 *$ & $.434^{*}$ \\
\hline Non-profit & & $-2.956^{* * *}$ & $-2.696 * * *$ & $-3.375^{* * *}$ \\
\hline \multicolumn{5}{|l|}{ Control variables } \\
\hline Married & & & -.026 & .259 \\
\hline LDS & & & $-.444 * * *$ & $-.494^{* * *}$ \\
\hline Hours billed & & & $.060 * * *$ & $.053^{* * *}$ \\
\hline Job tenure & & & $.087 * * *$ & $.085^{* * *}$ \\
\hline Firm size & & & $.006^{* * *}$ & $.006^{* * *}$ \\
\hline Has female superior & & & -.146 & -.106 \\
\hline \multicolumn{5}{|l|}{ Age $^{\mathrm{b}}$} \\
\hline 29 or younger & & & .017 & -.096 \\
\hline $40-49$ & & & $.414^{* *}$ & $.431^{* *}$ \\
\hline $50-59$ & & & $.473^{*}$ & $.488^{*}$ \\
\hline 60 or older & & & .333 & .357 \\
\hline \multicolumn{5}{|l|}{ Bar admittance ${ }^{c}$} \\
\hline $1985-1989$ & & & $1.226^{* * *}$ & $1.232^{* * *}$ \\
\hline $1990-1994$ & & & $.720 * * *$ & $.724^{* * *}$ \\
\hline $1995-1999$ & & & $.928^{* * *}$ & $.934^{* * *}$ \\
\hline \multicolumn{5}{|l|}{ Interaction terms (x gender) } \\
\hline Experienced discrimination & & & & -.002 \\
\hline Experienced harassment & & & & .601 \\
\hline Number of mentors & & & & .047 \\
\hline Number of children & & & & $-.274^{* * *}$ \\
\hline Percent females at job & & & & $-.010^{*}$ \\
\hline \multicolumn{5}{|l|}{ Employment sector } \\
\hline Government & & & & $.688^{*}$ \\
\hline Company (in-house) & & & & -.197 \\
\hline Non-profit & & & & $1.421^{*}$ \\
\hline Married & & & & -.271 \\
\hline Hours billed & & & & .009 \\
\hline $\mathrm{R}^{2}$ & .059 & .204 & .396 & .409 \\
\hline $\operatorname{Adj} R^{2}$ & .058 & .200 & .388 & .398 \\
\hline$[\mathrm{N}]$ & 1754 & 1754 & 1754 & 1754 \\
\hline
\end{tabular}

Note: 2007 earnings is treated as continuous; categories range from $1=$ "less than $\$ 40 \mathrm{~K} "$ to $13=$ " $\$ 500 \mathrm{~K}$ or more"

a The reference category is law firms

b The reference category is $30-39$

c The reference category is 2000-2005

${ }^{*} p<.05,{ }^{* *} p<.01,{ }^{* * *} p<.001$ (two-tailed tests). 
TABLE 3. Logistic Regressions (Odds Ratios) of High Assignment Quality Relative to Peers, Utah Attorney Advancement and Retention Survey, 2008-2009

\begin{tabular}{|c|c|c|c|c|c|}
\hline & Model 1 & Model 2 & Model 3 & Model 3a & Model 3b \\
\hline & & & & (Men) & (Women) \\
\hline \multicolumn{6}{|l|}{ Explanatory variables } \\
\hline Female & $.633^{* * *}$ & $.656^{* * *}$ & $.750^{*}$ & & \\
\hline \multicolumn{6}{|l|}{ Experienced } \\
\hline discrimination & & 1.559 & 1.378 & .517 & $2.034^{*}$ \\
\hline Experienced harassment & & 1.538 & 1.334 & 1.951 & 1.023 \\
\hline Number of mentors & & $1.059^{*}$ & 1.046 & 1.064 & 1.019 \\
\hline Number of children & & 1.000 & 1.032 & 1.042 & 1.006 \\
\hline Percent females at job & & .997 & .997 & $.993^{*}$ & 1.006 \\
\hline \multicolumn{6}{|l|}{ Employment sector ${ }^{\mathrm{a}}$} \\
\hline Government & & $.624^{* * *}$ & $.676^{* *}$ & .746 & $.489 * *$ \\
\hline Company (in-house) & & .816 & .857 & .914 & .553 \\
\hline Non-profit & & .828 & .950 & 1.148 & .561 \\
\hline \multicolumn{6}{|l|}{ Control variables } \\
\hline Married & & & .834 & .664 & .932 \\
\hline LDS & & & .782 & .770 & .890 \\
\hline Hours billed & & & $1.034 * * *$ & $1.038 * * *$ & $1.030 * *$ \\
\hline Job tenure & & & $1.030 * *$ & $1.032 *$ & 1.026 \\
\hline Firm size & & & 1.001 & 1.001 & 1.002 \\
\hline Has female superior & & & 1.243 & 1.263 & .966 \\
\hline \multicolumn{6}{|l|}{$\mathrm{Age}^{\mathrm{b}}$} \\
\hline 29 or younger & & & 1.411 & $2.943^{*}$ & .830 \\
\hline $40-49$ & & & .821 & .983 & .604 \\
\hline $50-59$ & & & .763 & .874 & .629 \\
\hline 60 or older & & & 1.132 & 1.506 & .617 \\
\hline \multicolumn{6}{|l|}{ Bar admittance $^{c}$} \\
\hline 1985-1989 & & & $1.736^{*}$ & 1.264 & $3.741 * * *$ \\
\hline 1990-1994 & & & 1.320 & 1.065 & 1.995 \\
\hline 1995-1999 & & & 1.289 & 1.048 & $1.958^{*}$ \\
\hline AIC & 3522.409 & 3390.344 & 2921.727 & & \\
\hline BIC & 3534.184 & 3449.126 & 3054.384 & & \\
\hline$[\mathrm{N}]$ & 1754 & 1754 & 1754 & 1176 & 578 \\
\hline
\end{tabular}

Note: Assignment quality is binary; $0=$ "equal or lower quality than peers," 1 = "higher quality than peers"

a The reference category is law firms

b The reference category is $30-39$

c The reference category is 2000-2005

${ }^{*} p<.05,{ }^{* *} p<.01,{ }^{* * *} p<.001$ (two-tailed tests). 